\title{
REVITALISASI KEGIATAN USAHA GETUK GORENG HJ. TOHIRIN DI MASA PANDEMI COVID-19
}

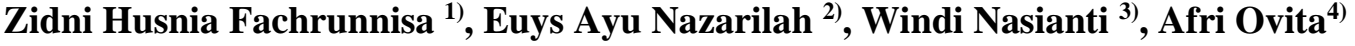 \\ 1) Program Sarjana Akuntansi, Fakultas Bisnis, Universitas PGRI Yogyakarta , e-mail :zidnifachrunnisa@upy.ac.id \\ 2) Program Sarjana Akuntansi, Fakultas Bisnis, Universitas PGRI Yogyakarta , e-mail: euysayu@ gmail.com \\ 3) Program Sarjana Akuntansi, Fakultas Bisnis, Universitas PGRI Yogyakarta, e-mail: nasiantiw@ gmail.com \\ 4) Program Sarjana Akuntansi, Fakultas Bisnis, Universitas PGRI Yogyakarta, e-mail :afriiovita@gmail.com
}

\begin{abstract}
Abstrak
Kegiatan pengabdian ini bertujuan untuk untuk mengatasi dampak Covid -19 terhadap UMKM Getuk Goreng Hj. Tohirin. Permasalahan utama yang dialami oleh UMKM Getuk Goreng Hj. Tohirin di masa pandemi Covid-19 yakni penurunan pendapatan akibat menurunnya jumlah wisatawan yang datang ke Sokaraja. Berdasarkan survei yang dilakukan, terdapat sub permasalahan yang terjadi pada UMKM Getuk Goreng Hj. Tohirin yakni Sumber Daya Manusia yang dimiliki UMKM yang kurang memahami teknologi. Solusi yang dilakukan untuk mengatasi permasalahan tersebut yakni pendampingan pemasaran dan penjualan daring dan pendampingan pemanfaatkan teknologi informasi untuk pencatatan transaksi keuangan. Hasil dari kegiatan pengabdian ini yakni munculnya akun media sosial, akun digital marketplace, dan laporan keuangan terkomputerisasi yang dapat dimanfaatkan UMKM Getuk Goreng $\mathrm{Hj}$. Thohirin dalam melakukan aktivitas bisnisnya. Kegiatan ini juga berhasil meningkatkan keterampilan karyawan untuk mengelola akun media sosial dan akun digital marketplace milik UMKM Getuk Goreng $\mathrm{Hj}$. Thohirin serta keterampilan membuat pembukuan dengan computer.
\end{abstract}

Kata Kunci: Covid-19, UMKM, Teknologi Informasi, Pembukuan

\begin{abstract}
This community service activity aims to overcome the impact of Covid -19 on SMEs Getuk Goreng Hj. Tohirin. The main problem that occurs at SMEs Getuk Goreng Hj. Tohirin during the Covid-19 pandemic, namely a decrease in income due to the decline in the number of tourists who came to Sokaraja. Based on the survey conducted, there are sub-problems that occur in Getuk Goreng SMEs Hj. Tohirin, namely Human Resources owned by SMEs who do not understand technology. Solutions taken to overcome these problems are assistance in online marketing and sales and assistance in the use of information technology for recording financial transactions. The results of this service activity are the emergence of social media accounts, digital marketplace accounts, and computerized financial reports that can be utilized by SMEs Getuk Goreng Hj. Thohirin in carrying out his business activities. This activity also succeeded in improving employees' skills to manage social media accounts and digital marketplace accounts belonging to SMEs Getuk Goreng $\mathrm{Hj}$. Thohirin and his computer bookkeeping skills.
\end{abstract}

Keywords: Covid-19, SMEs, Information Technology, Bookkeeping.

\section{PENDAHULUAN}

Saat ini dunia masih dilanda pandemi corona virus disease 2019 atau disingkat Covid-19.
Menyebarnya virus ini secara masif membuat Organisasi Kesehatan Dunia (WHO) menyatakan kondisi ini sebagai pandemi global. Di Indonesia, virus ini mulai diketahui menyebar pada 2 Maret 2020 yakni ketika 2 orang terkonfirmasi tertular dari 
seorang warga Negara Asing. Pada 9 April, virus sudah menyebar ke 34 provinsi dengan Jawa Timur, DKI Jakarta dan Sulawesi Selatan sebagai provinsi paling terpapar (Rosita, 2020). Untuk mengatasi kondisi tersebut, pemerintah melakukan pencegahan berupa kampanye 3M (Memakai masker, Mencuci tangan, Menjaga jarak) serta memberlakukan Pembatasan Sosial Berskala Besar (PSBB) dan mengkampanyekan Stay at Home.

Pandemi Covid-19 yang sedang terjadi memiliki dampak pada berbagai sektor industri, salah satunya adalah industri pariwisata. Dengan adanya pembatasan aktivitas masyarakat mengakibatkan industri pariwisata mengalami penurunan pendapatan. Dampak penurunan pariwisata terhadap Usaha Mikro Kecil Menengah (UMKM) yang bergerak di bidang makanan dan minuman mikro mencapai $27 \%$. Sedangkan dampak terhadap usaha kecil makanan dan minuman sebesar $1,77 \%$, dan usaha menengah di angka 0,07\% (Amri, 2020). Salah satu usaha yang terkena dampak pandemi Covid-19 ini adalah Getuk Goreng Hj. Tohirin. Usaha Getuk Goreng $\mathrm{Hj}$. Tohirin merupakan usaha di bidang oleholeh khas Sokaraja yakni Getuk Goreng yang terletak di Jl. Jendral Sudirman, Sokaraja, Banyumas. Usaha ini berdiri sejak tahun 1918, hingga saat ini memiliki 10 cabang. Usaha tersebut hanya mengandalkan sektor pariwisata sebagai lahan untuk memperoleh keuntungan. Usaha Getuk Goreng $\mathrm{Hj}$. Tohirin memiliki brand sebagai oleh-oleh khas Sokaraja, Banyumas. Dikutip dari www.suarabanyumas.com pada 7 Januari 2021, Wisatawan yang berkunjung ke Banyumas mengalami penurunan drastis, Pemerintah Kabupaten Banyumas hanya mencatat sebanyak 200.618 wisatawan yang berkunjung selama tahun 2020 (Editor 2021). Penurunan jumlah wisatawan Banyumas tersebut berdampak pada pemasukan Getuk Goreng Hj. Tohirin.

Perkembangan teknologi saat ini membuat semua aktivitas manusia dilakukan dengan digital terutama pada masa pandemi seperti saat ini. Aktivitas berbelanja dilakukan masyarakat melalui $e$ commerce sehingga dapat menghindari aktifitas bertatap muka dan juga memberi kemudahan berbelanja. Menurut Bank Indonesia transaksi jual beli di perdagangan elektronik meningkat dua kali lipat di masa pandemic Covid-19 yakni melonjak dari 80 juta transaksi pada tahun 2019 menjadi 140 juta transaksi pada Agustus 2020 (Uli 2020). Selama ini, Getuk Goreng Hj. Tohirin hanya mengandalkan wisatawan yang datang ke Banyumas untuk memperoleh keuntungannya. Sehingga perlu adanya transformasi strategi pemasaran dan penjualan Getuk Goreng $\mathrm{Hj}$. Tohirin. Namun, permasalah yang dihadapi Getuk Goreng Hj. Tohirin yakni Sumber Daya Manusia yang kurang memahami teknologi karena sebagian besar karyawan merupakan karyawan yang sudah lama bekerja.

Teknologi tidak hanya bermanfaat untuk mempermudah transaksi, tetapi juga aktifitas seperti pengelolaan keuangan dan administrasi bisnis. Menurut Setiawati (2007), Teknologi Informasi (TI) memberikan kemudahan dalam mengolah, mengelola dan menyajikan informasi keuangan, sehingga dapat tercapai keunggulan kompetitif bagi perusahaan. Tujuan penerapan teknologi informasi bagi bisnis adalah untuk mendapatkan peningkatan efektivitas dan efisiensi dalan semua aspek rantai nilai. Teknologi informasi merubah cara kerja manusia, cara memproduksi, cara mengkoordinasi, cara berpikir. Pemanfaatan teknologi informasi menyebabkan perubahan-perubahan besar telah terjadi melalui teknologi informasi di dalam organisasi (Machmudi, 2019). Sehingga dengan menerapkan teknologi informasi yang tepat akan meningkatkan keuntungan pada sebuah bisnis. Permasalahan pada UMKM Getuk Goreng $\mathrm{Hj}$. Tohirin yakni sistem pembukuan usaha masih dilakukan secara manual karena Sumber Daya Manusia yang kurang memahami teknologi tersebut.

Berdasarkan permasalahan diatas, maka kegiatan sebagai upaya untuk mengatasi dampak Covid-19 terhadap UMKM Getuk Goreng $\mathrm{Hj}$. Tohirin. Kegiatan yang dilakukan antara lain dengan membantu mengubah strategi pemasaran dan penjualan serta memanfaatkan teknologi informasi untuk pencatatan transaksi keuangan. Capaian dari kegiatan ini meningkatnya keterampilan karyawan UMKM Getuk Goreng $\mathrm{Hj}$. Thohirin dalam melakukan pemasaran dan penjualan secara daring. Serta meningkatnya keterampilan karyawan UMKM Getuk Goreng Hj. Thohirin dalam melakukan 
pembukuan dengan komputer. Sebagai luaran dari kegiatan ini yakni adanya media sosial yang digunakan sebagai media pemasaran daring dan adanya akun Digital Marketplace untuk penjualan daring produk Getuk Goreng Hj. Thohirin. Selain itu, juga terdapat kerangka pembukuan dengan komputer yang nantinya dapat dilanjutkan oleh pihak UMKM.

\section{METODOLOGI PENGABDIAN}

Pelaksanaan kegiatan pengabdian masyarakat di UMKM Getuk Goreng Haji Tohirin dilakukan secara luring dan daring selama satu bulan. Pelaksanaan kegiatan dilakukan dari tanggal 14 September 2020 hingga 14 November 2020. Adapun tahapan dan metode pelaksanaan kegiatan yang dilakukan adalah sebagai berikut:

\section{Tahap Persiapan}

Persiapan dilakukan dengan melakukan survei pendalaman masalah yang dilakukan dengan wawancara. Kemudian pengabdi mendiskusikan solusi untuk permasalahan yang dialami UMKM. Selanjutnya, pengabdi mengkoordinasikan usulan solusi kepada pihak UMKM dan membuat perencanaan pelaksanaan kegiatan.

\section{Tahap Pelaksanaan.}

Tahap pelaksanaan yang dilakukan pengabdi melalui beberapa metode yakni:

\section{a. Sosialisasi pentingnya pembukuan}

Dalam bisnis, akuntansi atau pecatatan keuangan sangat diperlukan seperti sebagai dasar perencanaan bisnis dan sebagai upaya untuk mendapatkan modal tambahan (Kurniawanysah 2016). Menurut Romindo et al. (2020), Teknologi informasi dan teknologi komputer mendukung penyampaian dan pengolahan informasi menjadi lebih efektif dan efisien. Penggunaan teknologi juga dapat membantu para pelaku UMKM untuk tidak perlu mempelajari tahapan demi tahapan siklus akuntansi manual yang dirasa rumit (Achadiyah 2019). Kegiatan ini bertujuan untuk memberikan infromasi mengenai manfaat dari penggunaan teknologi informasi dalam aktivitas bisnis serta memberikan beberapa alternatif sistem pencatatan keuangan digital yang bisa UMKM gunakan sesuai dengan kemampuan UMKM. Kegiatan ini dilakukan secara daring dengan peserta yakni pemilik dan karyawan yang bertanggung jawab di bagian keuangan.

\section{b. Pendampingan Pembukuan}

Kegiatan ini merupakan lanjutan dari kegiatan sosialisasi pentingnya pembukuan, yang bertujuan untuk memperdalam pengetahuan mengenai pembukuan dan melatih karyawan agar dapat mengaplikasikannya. Pendampingan dilakukan pada setiap proses akuntansi. Menurut Jusup (2001), proses akuntansi meliputi, pencatatan, penggolongan, peringkasan, pelaporan dan penganalisa data keuangan. Berdasarkan hasil penelitian menunjukkan bahwa pembuatan sistem akuntansi yang berbasis excel dapat membantu pelaku UMKM dalam mengelola keuangan dan pengambilan keputusan (Achadiyah 2019). Sehingga, pengabdi menggunakan Microsoft Excel untuk melaksanakan kegiatan ini.

\section{c. Pendampingan Pemasaran Daring}

Menurut Rosita (2020) pemasaran digital mampu membuat Industri ritel mampu bertahan di masa pandemi. Kegiatan ini bertujuan untuk membantu karyawan UMKM menggunakan media sosial yang akan digunakan sebagai media pemasaran dan penjualan daring. Media sosial dipilih karena meningkatnya pengguna media sosial terlebih di masa pandemi. Hal ini akan membantu kegiatan pemasaran Getuk Goreng $\mathrm{Hj}$. Tohirin.

\section{d. Pendampingan penjualan daring}

Kegiatan ini bertujuan untuk membantu UMKM mengatasi permasalahan utama yakni penurunan penjualan akibat pandemi Covid-19. Digital Marketplace yang ada dipilih sebagai media berjualan daring. Keuntungan Digital Marketplace yakni pelaku usaha tidak perlu mengeluarkan biaya mahal untuk membangun dan mengelola sistem karena sudah dilakukan oleh pengelola digital markerplace (Yustiani and Yunanto 2017). Adanya Pandemi Covid 19 yang melanda seluruh Wilayah Indonesia dan diterapkannya Peraturan Pembatasan 
Sosial Berskala Besar (PSBB) akan memudahkan penjualan Getuk Goreng.

\section{e. Sosialisasi e-Filing}

e-Filing merupakan suatu cara penyampaian Surat Pemberitahuan Pajak Tahunan (SPT Tahunan) secara elektronik yang dilakukan secara online dan realtime melalui internet pada website Direktorat Jendral Pajak (www.pajak.go.id) atau Penyedia Jasa Aplikasi Perpajakan (PJAP). Menurut Avianto, Rahayu, and Kaniskha (2016), e-Filing dapat membuat wajib pajak melaksanakan kewajiban pajaknya yakni melaporkan SPT Tahunan dengan lebih efisien. Kegiatan ini dilakukan dengan tujuan agar selain melakukan pembukuan akuntansi UMKM juga membantu mereka dalam melakukan penyetoran pajak secara daring yang dapat mempermudah UMKM karena jumlah UMKM yang di miliki lebih dari satu cabang.

\section{Tahap Evaluasi Kegiatan}

Tahap ini dilakukan pada akhir pengabdian untuk mengevaluasi apakah capaian kegiatan pengabdian ini dapat terpenuhi. Evaluasi dilakukan melalui wawancara kepada pemilik serta karyawan yang merupakan peserta kegiatan ini.

\section{PELAKSANAAN KEGIATAN}

\section{a. Tahap Persiapan}

Sebelum pelaksanaan kegiatan dimulai, pengabdi melakukan berbagai persiapan baik koordiansi tim maupun koordinasi dengan pihak UMKM. Langkah pertama setelah koordinasi dengan pihak UMKM adalah wawancara kepada pemilik yang dilakukan pada tanggal 14 September 2020. Dari kegiatan ini, diketahui kendala apa saja yang dihadapi oleh pihak UMKM selama pandemi Covid-19. Disini tim pengabdi memperoleh beberapa informasi terkait kendala yang sedang dihadapi pihak UMKM yakni masalah pembukuan, SDM yang kurang memadai serta penggunaan teknologi yang masih minim dan penjualan yang menurun. Maka dari itu, dengan adanya kegiatan ini diharapkan masalah masalah yang dihadapi oleh UMKM yakni Usaha Getuk
Goreng Hj. Tohirin bisa diselesaikan atau memperoleh jalan keluar dari permasalahan tersebut.

Langkah kedua, pengabdi melakukan koordinasi tim untuk menentukan solusi atas permasalahan yang dialami UMKM untuk diusulkan kepada UMKM. Langkah terakhir, pengabdi melakukan koordinasi solusi kepada UMKM dilakukan pada tanggal 21 September 2020. Solusi yang akan dilakukan yakni sosialisasi pentingnya pembukuan, pendampingan pembukuan, pendampingan pemasaran daring, pendampingan penjualan daring, dan sosialisasi $e$ Filing.

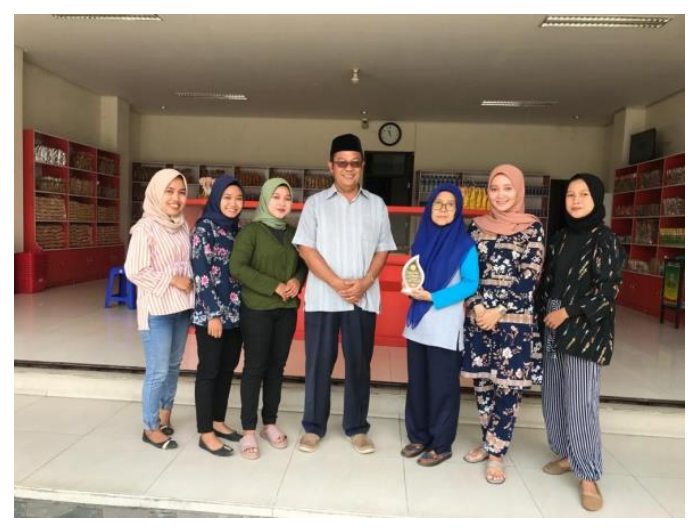

Gambar 1. Kegiatan Survei dengan Pemilik UMKM

\section{b. Tahap Pelaksanaan}

a. Sosialisasi Pentingnya Pembukuan

Kegiatan ini dilakukan secara daring dengan menggunakan media Google Meet. Kegiatan sosialisasi pentingnya pembukuan ini dilakukan dengan penyampaian materi yang disampaikan oleh Zidni Husnia Fachrunnisa. M.Ak selaku dosen Program Studi Akuntansi Universitas PGRI Yogyakarta. Kegiatan ini juga memberikan kesempatan bagi pihak Usaha Getuk Goreng $\mathrm{Hj}$. Tohirin untuk berdiskusi terkait pembukuan. Kegiatan ini dihadiri oleh pemilik dan karyawan yang bertanggung jawab di bagian keuangan. Kegiatan ini berlangsung sebanyak satu kali pertemuan dengan durasi 1,5 jam. 
Gambar 2. Sosialisasi pembukuan melalui daring

b. Pendampingan Pembukuan

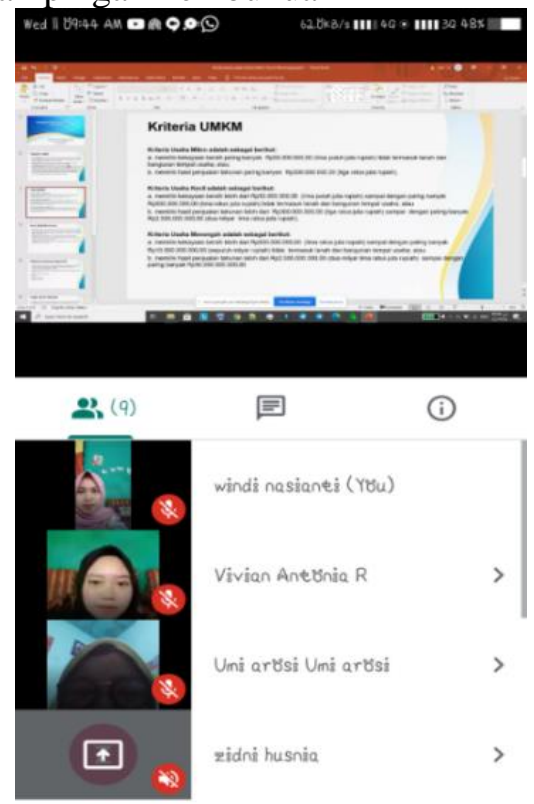

Pembukuan yang dilakukan oleh Usaha Getuk Goreng Hj. Tohirin masih dilakukan secara manual menggunakan buku pembantu yang berisi rincian transaksi yang dilakukan usaha Getuk Goreng $\mathrm{Hj}$. Tohirin per hari nya, baik itu transaksi pembelian maupun penjualan dan transaksi lain yang berhubungan dengan operasional. Sehingga dalam kegiatan ini, proses dilaksanakan dengan mendampingi karyawan menginput data yang ada pada buku pembantu ke Microsoft Excel dengan menyesuaikan dengan nota transaksi. Kegiatan ini dilakukan selama 2 (dua) minggu berturut - turut dengan durasi masing - masing selama 2,5 jam.

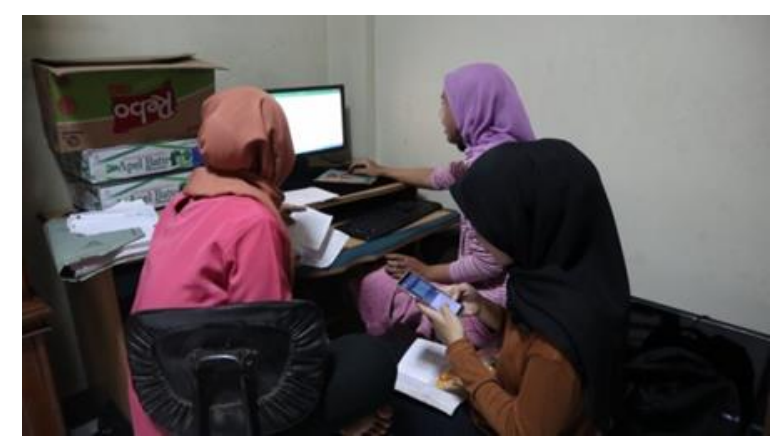

Gambar 3. Pendampingan pembukuan dengan computer

\section{c. Pendampingan Pemasaran Daring}

Kegiatan pemasaran daring dilakukan dengan membantu pemasaran lewat pembuatan akun media sosial. Media yang digunakan dalam kegiatan ini berupa gambar dan video. Media sosial dipilih seperti Instagram, Tik Tok, serta Youtube. Kegiatan ini dilakukan secara daring dengan koordinasi jarak jauh melalui Whatsapp selama 2 minggu berturut turut.

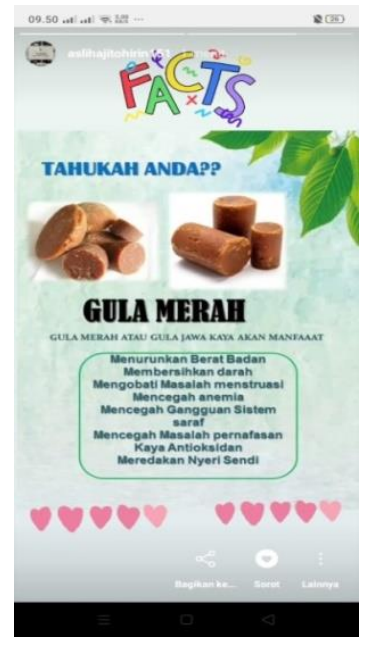

Gambar 4. Dokumentasi Pemasaran Daring

\section{d. Pendampingan Penjualan Daring}

Kegiatan ini dilakukan secara daring dengan koordinasi jarak jauh melalui Whatsapp selama 2 minggu berturut turut bersamaan dengan pemasaran daring. Kegiatan ini dilakukan dnegan mendampingi karyawan dalam mengoperasikan Digital Marketplace seperti Shopee, Lazada, Tokopedia dan lainnya yang menjadi andalan saat ini.

\section{Sosialisasi $e$-Filing}

Kegiatan ini dilakukan kepada seluruh karyawan kantor dari 7 cabang yang dikelola oleh UMKM Getuk Goreng Hj. Tohirin. Kegiatan ini dilaksanakan secara luring, yakni dilaksanakan di kantor Usaha Getuk Goreng Hj. Tohirin. Kegiatan ini dilakukan sebanyak 1 (satu) kali pertemuan dengan durasi 2 jam, yang terdiri dari memberikan petujuk dan arahan pengisian e-Filing untuk pelaporan pajak yang lebih mudah. 


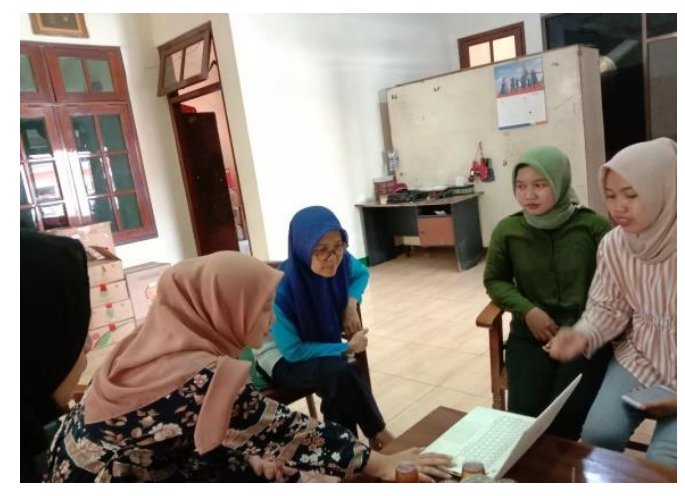

Gambar 5. Sosialisasi $e$-Filing kepada karyawan

\section{c. Tahap Evaluasi Kegiatan}

Tahap ini dilakukan pada akhir pengabdian untuk mengevaluasi apakah capaian kegiatan pengabdian ini dapat terpenuhi. Evaluasi dilakukan melalui wawancara kepada pemilik serta karyawan yang merupakan peserta kegiatan ini. Sebagai keberlanjutan program, program kerja yang pengabdi lakukan pada UMKM Getuk Goreng Hj. Tohirin akan tetap pengabdi lanjutkan hingga UMKM Getuk Goreng Hj. Tohirin dapat menerapkan program kerja secara maksimal. Pengabdi terus untuk melakukan komunikasi dengan pihak UMKM baik dengan pihak pemilik dan karyawan UMKM Getuk Goreng $\mathrm{Hj}$. Tohirin melalui pesan WhatsApp.

\section{HASIL DAN PEMBAHASAN}

Hasil dari kegiatan pengabdian yang dilakukan pada UMKM Getuk Goreng Hj. Thohirin yang dilakukan dilakukan dari tanggal 14 September hingga 14 November 2020 terdiri dari beberapa tahapan yaitu sosialisasi pentingnya pembukuan, pendampingan pembukuan, pendampingan pemasaran daring, pendampingan penjualan daring dan sosialisasi $e$ filling.

\section{Sosialisasi Pentingnya Pembukuan}

Kegiatan ini berlangsung sebanyak satu kali pertemuan yang dilakukan pada tanggal 19 Oktober 2020 dengan durasi 1,5 jam. Peserta yang hadir yakni pemilik UMKM Getuk Goreng Hj. Thohirin serta karyawan yang bertanggung jawab pada bagian administrasi. Kegiatan ini dilakukan dengan metode dua arah, peserta aktif mengikuti kegiatan ini dengan menanyakan beberapa solusi dari beberapa kendala permasalahan pembukuan. Selama ini, di UMKM tersebut melakukan pencatatan transaksi keuangan secara manual dan tanpa prosedur yang jelas. Keuangan dalam bisnis dan pribadi yang bersumber dari pemilik masih bercampur menjadi satu. Sehingga, UMKM tidak dapat mengetahui jelas informasi keuangan pada bisnisnya. Untuk itu, dalam kegiatan ini pengabdi melalui pemateri kegiatan, memberikan penyuluhan pentingnya sistem pembukuan pada bisnis, serta memberikan pengetahuan bagaimana prosedur yang benar dalam melakukan pembukuan. Hasil dari kegiatan ini, peserta pihak UMKM memahami akan pentingnya sistem pembukuan serta bagaimana prosedur yang benar dalam melakukan pembukuan. Untuk itu, pihak UMKM berkomitmen untuk memperbaiki sistem pencatatan melalui pendampingan yang akan pengabdi berikan serta mengusahakan memiliki software akuntansi yang memadai.

\section{Pendampingan Pembukuan}

Kegiatan ini dilaksanakan selama kurang lebih dua minggu dari tanggal 20 Oktober hingga 4 November 2020. Kegiatan ini dilaksanakan di kantor Usaha Getuk Goreng $\mathrm{Hj}$. Tohirin. Pembukuan yang dilakukan adalah data tahun 2018 dan 2020, pelaksanaan kegiatan menggunakan media Microsoft Excel. Pendampingan pembukuan yakni dengan rincian sebagai berikut:
a. Pembaharuan daftar harga beli dan harga jual produk
b. Membuat jurnal peneriamaan kas
c. Membuat jurnal pengeluaran kas
d. Membuat jurnal penjualan
e. Membuat jurnal pembelian
f. Membuat buku besar dan neraca saldo
g. Membuat laporan keuangan

\section{Pendampingan Pemasaran Daring}

Proses pemasaran yang dilakukan adalah dengan mengambil gambar dan membuat video pemasaran melalui Story Wahatsapp, Story Instagram, Feed Instagram, dan TikTok. Kegiatan ini dilakukan secara daring dengan koordinasi dengan pihak UMKM jarak jauh melalui Whatsapp selama kurang 
lebih 2 minggu berturut turut dari tanggal 5 November hingga 13 November 2020. Hasil dari kegiatan ini yakni UMKM Getuk Goreng $\mathrm{Hj}$. Tohirin dapat melakukan pemasaran melalui daring dan karyawan mampu mengoperasikan media social UMKM dengan baik. Harapannya UMKM Getuk Goreng $\mathrm{Hj}$. Tohirin dapat bertahan dimasa pandemi seperti saat ini dan dapat memperluas pasar kedepannya.

\section{Pendampingan Penjualan Daring}

Digital Digital Marketplace yang dipilih sebagai tempat berjualan secara daring yakni Shopee dan Tokopedia. Kegiatan ini dilakukan secara daring dengan koordinasi jarak jauh melalui Whatsapp selama 2 minggu berturut turut bersamaan dengan pemasaran daring. Kegiatan ini dilakukan bersamaan dengan pendampingan pemasaran daring yakni tanggal 5 November hingga 13 November 2020. Kegiatan ini meliputi membuat diskripsi dan menambahkan produk di e-commerce seperti Shopee dan Tokopedia. Hasil dari kegiatan ini yakni UMKM Getuk Goreng $\mathrm{Hj}$. Tohirin dapat melakukan penjualan melalui daring dan karyawan mampu mengoperasikan akun e-commerce UMKM dengan baik. Sehingga, UMKM Getuk Goreng Hj. Tohirin harapannya dapat bertahan dimasa pandemi seperti saat ini dan dapat meningkatkan omset kedepannya.

\section{Sosialisasi $e$-Filing}

Kegiatan ini dilaksanakan pada tanggal 14 November 2020. Pelaksanaan kegiatan ini dihadiri oleh pegawai yang bertanggung jawab atas keuangan di usaha Getuk Goreng Hj. Tohirin. Kegiatan ini dilakukan sebanyak 1 (satu) kali pertemuan dengan durasi 2 jam, yang terdiri dari memberikan petujuk dan arahan pengisian e-Filing. Hasil dari kegiatan ini, karyawan memahami penggunaan e-Filing dan berkomitmen untuk melaporkan pajak dengan tepat.

Secara ringkas, hasil yang didapatkan oleh pihak UMKM dengan adanya kegiatan pengabdian ini adalah :

a. Pembukuan yang dulunya dilakukan secara manual kini sudah bisa memanfaat teknologi yang ada seperti penggunaan Ms. Excel b. Pembaruan daftar harga beli dan jual untuk produk yang dijual di UMKM memudahkan untuk mengetahui Harga Pokok Produksi dan laba rugi UMKM selanjutnya

c. Pembuatan akun bisnis pada Tokopedia dan Shopee, membuat penjualan Gethuk sekarang tidak hanya penjualan di toko namun sudah bisa dibeli juga melalui daring

d. Media pemasaran melalui instagram kini kembali aktif lagi

e. Tidak hanya instagram, media sosial yang bisa dimanfatakan untuk pemasaran yakni TikTok

f. Media pemasaran juga lebih menarik yakni dengan video pemasaran yang dibagikan ke Instagram, TikTok, dan WhatsApp Getuk Goreng $\mathrm{Hj}$. Tohirin

Selama kurang lebih 4 (empat) minggu melakukan pengabdian di Getuk Goreng Haji Tohirin, berikut capaian program yang direalisasikan:

Tabel 1. Capaian Kegiatan

\begin{tabular}{|c|c|}
\hline Capaian & Keterangan \\
\hline $\begin{array}{l}\text { Meningkatnya } \\
\text { keterampilan }\end{array}$ & $\begin{array}{lr}\text { Karyawan mampu melakukan } \\
\text { pembukuan }\end{array}$ \\
\hline karyawan & mengkategorikan kedalam \\
\hline Getuk Goreng $\mathbf{H j}$. & akun, meng input transaksi \\
\hline $\begin{array}{ll}\text { Thohirin } & \text { dalam } \\
\text { melakukan } & \\
\text { pembukuan } & \text { dengan } \\
\text { komputer. } & \end{array}$ & $\begin{array}{l}\text { kedalam Ms. Excel, dan } \\
\text { menyusun buku besar dan } \\
\text { membuat laporan keuangan } \\
\text { berupa neraca saldo. }\end{array}$ \\
\hline $\begin{array}{l}\text { Meningkatnya } \\
\text { keterampilan }\end{array}$ & $\begin{array}{l}\text { - Karyawan } \\
\text { mengoperasikan }\end{array}$ \\
\hline karyawan UMKM & Sosial berupa Tiktok dan \\
\hline Getuk Goreng $\mathbf{H j}$. & Instagram untuk pemasaran \\
\hline $\begin{array}{l}\text { Thohirin dalam } \\
\text { melakukan pemasaran } \\
\text { dan penjualan secara } \\
\text { daring. }\end{array}$ & $\begin{array}{l}\text { - Karyawan mampu } \\
\text { mengoperasikan Shopee dan } \\
\text { Tokopedia untuk berjualan } \\
\text { daring }\end{array}$ \\
\hline
\end{tabular}

\section{Ucapan Terima Kasih}

Tim pengabdi ucapkan terima kasih atas partisipasi pihak UMKM Getuk Goreng Hj. Tohirin. Ucapan terima kasih juga pengabdi sampaikan untuk fakultas bisnis Universitas PGRI Yogyakarta yang telah memberi dukungan untuk pelaksanaan kegiatan pengabdian ini.

\section{PENUTUP}

Kesimpulan

Kegitan pengabdian masyarakat ini bertujuan untuk mengatasi dampak Covid -19 terhadap UMKM Getuk Goreng Hj. Tohirin. Kegiatan yang dilakukan 
antara lain dengan membantu mengubah strategi pemasaran dan penjulan. UMKM Getuk Goreng $\mathrm{Hj}$. Tohirin yang tadinya hanya melakukan pemasaran dan penjulan dengan cara yang konvensional yakni bergantung pada pembeli yang datang langsung ke toko, menambah cara pemasaran dan penjulan dengan cara daring. Selain itu, kegiatan ini dapat membantu UMKM Getuk Goreng Hj. Tohirin memanfaatkan teknologi informasi untuk pencatatan transaksi keuangan agar lebih efisien dan efektif untuk mencapai laba yang diinginkan. Kegiatan ini dilakukan dengan sosialisasi dan pendampingan yakni Sosialisasi pentingnya pembukuan, pendampingan pembukuan, pendampingan pemasaran daring, pendampingan penjualan daring, dan sosialisasi e-Filing. Hasil yang dicapai dari kegiatan ini yakni Karyawan mampu melakukan pembukuan dengan Ms. Excel, Karyawan mampu mengoperasikan Media Sosial berupa Tiktok dan Instagram untuk pemasaran , dan Karyawan mampu mengoperasikan Shopee dan Tokopedia untuk berjualan daring. Luaran dari kegiatan ini juga tercapai yakni adanya media sosial TikTok yang digunakan sebagai media pemasaran daring dan adanya akun digital Digital Marketplace untuk penjualan daring produk Getuk Goreng $\mathrm{Hj}$. Thohirin seperti Shopee dan Tokopedia. Serta terdapat kerangka pembukuan dengan komputer yang nantinya dapat dilanjutkan oleh pihak UMKM.

\section{Saran}

Saran untuk pihak UMKM terutama untuk keberlanjutan program yang sudah ada yakni pihak UMKM kedepan dapat melakukan pembukuan secara Automatisasi untuk mempermudah dan mempercepat proses pembuatan laporan keuangan, Memberikan pelatihan kepada karyawan, jika akan menggunakan Software Akuntansi dalam kegiatan Usaha. Serta UMKM dapat memberitahukan kepada pelanggan bahwa Getuk Goreng $\mathrm{Hj}$. Tohirin juga melakukan penjualan secara daring.

\section{DAFTAR PUSTAKA}

Amri, Andi. 2020. "Dampak Covid-19 Terhadap Umkm Di Indonesia.” Jurnal Brand 2(1).

Avianto, Gusma Dwi, Sri Mangesti Rahayu, and Bayu Kaniskha. 2016. "Analisa Peranan EFiling Dalam Rangka Meningkatkan
Kepatuhan Pelaporan Surat Pemberitahuan Tahunan Wajib Pajak Orang Pribadi(Studi Pada Kantor Pelayanan Pajak Pratama Malang Selatan)." Jurnal Perpajakan (JEJAK) 9(1): 18.

Bety Nur Achadiyah. 2019. "Otomatisasi Pencatatan Akuntansi Pada Umkm." Jurnal Akuntansi Multiparadigma 10(1).

Editor, Staff. 2021. "Jumlah Wisatawan Ke Banyumas Turun Drastis." Suara Banyumas. www.suarabanyumas.com.

Jusup, Al. Haryono. 2001. Dasar-Dasar Akuntansi. Yogyakarta: STIE.

Kurniawanysah, Deddy. 2016. "Penerapan Pencatatan Akuntansi Dan Penyusunan Laporan Keuangan Berdasarkan SAK ETAP Pada UMKM Desa Gembongsari Kecematan Kalipuro Kabupaten Banyuwangi." Dinamika Global: Rebranding Keunggulan Kompetitif Berbasis Kearifan Lokal: 832-41.

Machmudi, Moch Ali. 2019. "Peran Teknologi Informasi Dalam Usaha Meraih Kesempatan Masa Depan Organisasi." Jurnal Transformasi 15(1): 87-95.

Romindo, Romindo et al. 2020. Sistem Informasi Bisnis. Medan: Yayasan Kita Menulis.

Rosita, Rahmi. 2020. "Pengaruh Pandemi Covid-19 Terhadap Umkm.” Jurnal Lentera Bisnis 9(2): 109-20.

Setiawati, Ira. 2007. "Peran Teknologi Informasi Dalam Pengembangan Sistem Informasi Akuntansi ( SIA ) ( The Role of Information Technology to Developt Accounting Information System as A Tools to Increase A Corporate Performance )." Fokus Ekonomi 2(1): 47-55.

Uli. 2020. "Transaksi E-Commerce Naik Nyaris Dua Kali Lipat Saat Pandemi." CNN Indonesia. www.cnnindonesia.com.

Yustiani, Rini, and Rio Yunanto. 2017. "Peran Marketplace Sebagai Alternatif Bisnis Di Era Teknologi Informasi." Komputa : Jurnal Ilmiah Komputer dan Informatika 6(2): 43-48. 